\title{
EPISODIC STUPOR ASSOCIATED WITH AN ECK FISTULA IN THE HUMAN WITH PARTICULAR REFERENCE TO THE METABOLISM OF AMMONIA ${ }^{1,2}$
}

\author{
BY WILLIAM V. MCDERMOTT, JR. AND RAYMOND D. ADAMS \\ (From the Surgical and Neurological Services, Massachusetts General Hospital, and the De- \\ partments of Surgery and Neurology, Harvard Medical School, Boston, Mass.)
}

(Submitted for publication June 16, 1953; accepted September 1, 1953)

The effect on animals of ligating the portal vein and diverting the blood from the portal system directly into the inferior vena cava through a surgically constructed fistula was first studied by Eck in 1877 (1). As a mark of respect for the ingenuity of these experiments, the eponym, "Eck fistula," has been perpetuated in medical writings. Animals so treated can be made to survive for long periods of time in apparently good health and therefore the Eck fistula has been used extensively as a means of investigating the metabolic activities of the liver. Although dogs with an Eck fistula may remain in good clinical condition, it has been demonstrated that the liver undergoes a certain amount of atrophy; the production of plasma proteins, hemoglobin, and bile pigments is diminished; serum lipid levels are low despite adequate fat absorption; and the consumption and urinary output of water are increased (2-5). Perhaps the most interesting and controversial observation derived from these experiments has been the phenomenon of "meat intoxication," a neurological disorder consisting of stupor, ataxia, convulsions, and finally coma, which occurs in Eck fistula dogs either after the ingestion of meat, or spontaneously. This phenomenon has been studied extensively $(6-10)$ and, while it has been suggested that various degradation products of protein metabolism are responsible, the pathogenesis actually remains obscure.

Construction of an anastomosis between the portal vein and the inferior vena cava with or without interruption of the portal vein is frequently carried out in patients with portal hypertension for the treatment of esophageal varices. This anasto-

\footnotetext{
1 The biochemical studies were supported by the Atomic Energy Commission and the Damon Runyon Fund.

2 The expense of the neurological studies was defrayed by grant No. B36 from the U. S. Public Health Service.
}

mosis undoubtedly reduces the pressure within the portal system and some portal blood flows through the new channel directly into the inferior vena cava. Nevertheless, the presence of pre-existing obstruction to the portal flow, either intrahepatic or extrahepatic, almost invariably has favored the development of an extensive collateral circulation, and blood may reach the liver through the hepatopedal channels described by Edwards (11). Therefore, the conditions of a true Eck fistula are not reproduced.

Recently, in a modification of existing surgical methods for the treatment of cancer of the head of the pancreas one of us (W. V. M.) (12) described the techniques which make it feasible to resect the portal vein and to construct an anastomosis between the superior mesenteric vein and the inferior vena cava. So far as is known, the performance of this procedure has resulted in the first Eck fistula to be established in man in the absence of pre-existing portal hypertension and collateral venous circulation. The case which was described in the above report offered an unusual opportunity to study the physiologic effects of this surgical anomaly and for this reason a number of metabolic studies were instituted. The findings of these studies are not presented here in detail because their significance was overshadowed by the extraordinary clinical course of the patient, i.e., the occurrence of episodic stupor. This neurologic disorder was transient, completely reversible and unaccompanied by any demonstrable biochemical change other than intermittent, precipitous elevations of the concentration of ammonia in the blood.

\section{CASE REPORT}

A. S. (MGH No. 752571 ), a 69 year-old retired Italian laborer, entered the Massachusetts General Hospital on September 25, 1951 with jaundice of several weeks' dura- 
tion. The clinical and laboratory findings pointed to an obstructive origin of the jaundice, and on October 8, 1951, an exploratory laparotomy was performed. A hard, nodular cancer measuring $5.0 \mathrm{~cm}$. in greatest diameter was found in the head of the pancreas. The tumor invaded the superior mesenteric vein near its junction with the splenic vein and in order to perform a pancreatoduodenectomy it was necessary to resect the portal vein. The end of the superior mesenteric vein was then joined to the side of the inferior vena cava thus establishing a true Eck fistula. No distant metastases were seen, and except for bile stasis the liver appeared normal by gross examination.

Postoperatively, the jaundice rapidly subsided and the immediate clinical course was uneventful. The patient was discharged from the hospital on the nineteenth postoperative day. Five weeks after operation he was readmitted in order that metabolic studies could be carried out and at this time he was in excellent health. On the fourth day in the hospital he became irrational and disoriented and was incontinent of urine. This episode, which progressed to stupor, developed over a period of several hours and lasted two or three days after which mental function then returned to normal. One month later, while still in the hospital, these symptoms recurred and this time the stupor progressed to coma. There were no focal neurological signs. Again spontaneous recovery took place. A third episode, identical in type to the others, occurred after a further interval of three weeks. It was the opinion of the attending physicians and consultants that these episodes of stupor or coma represented attacks of apoplexy and it was so stated in the original report of the case (12).

After he had recovered completely from this third epi- sode, the patient returned to his home and remained entirely asymptomatic until March 25, 1952. Once again he became confused and then comatose and was readmitted in this state. As in previous attacks there were no focal neurological signs and cardiac and renal functions remained normal. The function of the liver had not been greatly altered as judged by standard laboratory tests (Table I). There had been evidence of a mild impairment of carbohydrate and fat metabolism immediately after the operation, as revealed by tests of glucose tolerance and fat absorption, but not of a degree sufficient to account for a disturbance of nervous function of this severity. A total nitrogen balance study, including measurements of non-protein nitrogen, urea nitrogen, creatine and creatinine, demonstrated no abnormalities.

Despite the lack of laboratory evidence of any gross physiological abnormality, it became obvious that these episodic disturbances of consciousness were stereotyped in pattern and could only represent the effect of some unknown metabolic disorder on the nervous system. Consequently, it was decided to define the nature of the neurological syndrome by clinical and electroencephalographic methods and to search for possible clues as to the underlying biochemical abnormality.

\section{METHODS}

In order to obtain a more precise evaluation of the clinical status of the patient for purposes of correlation with electroencephalographic and biochemical data, the degrees of impairment of mental function were graded on a scale of zero to four. Normal mental function was recorded as zero. Coma, meaning a complete lack of awareness of any externally applied stimulus, was graded as

TABLE I

Preoperative and postoperative chemistries relative to liver function

\begin{tabular}{|c|c|c|c|c|c|c|c|c|c|c|}
\hline \multirow{2}{*}{$\begin{array}{l}\text { Date } \\
1951\end{array}$} & \multirow{2}{*}{$\begin{array}{c}\text { Vandenbergh } \\
m \boldsymbol{m} \text {. \% } \\
\text { direct/indirect }\end{array}$} & \multicolumn{2}{|c|}{$\begin{array}{l}\text { Cephalin } \\
\text { flocculation }\end{array}$} & \multirow{2}{*}{$\begin{array}{c}\text { Thymol } \\
\text { turbidity } \\
\text { units \% }\end{array}$} & \multirow{2}{*}{$\begin{array}{c}\text { Alkaline } \\
\text { p'tase } \\
\text { Bodansky } \\
\text { units \% }\end{array}$} & \multirow{2}{*}{$\begin{array}{c}\text { Uro- } \\
\text { bilinogen } \\
\text { urine } \\
\text { Ehrlich } \\
\text { units }\end{array}$} & \multirow{2}{*}{$\begin{array}{l}\text { Pro- } \\
\text { thrombin } \\
\text { time } \\
\% \text { of } \\
\text { normal }\end{array}$} & \multirow{2}{*}{$\begin{array}{c}\text { Total } \\
\text { protein } \\
\mathbf{G m} . \%\end{array}$} & \multirow{2}{*}{$\begin{array}{l}\mathbf{A} / \mathrm{G} \\
\text { ratio }\end{array}$} & \multirow{2}{*}{$\begin{array}{c}\text { Brom- } \\
\text { sulfalein } \\
\% \text { reten- } \\
\text { tion }\end{array}$} \\
\hline & & $24^{\circ}$ & $48^{\circ}$ & & & & & & & \\
\hline \multirow{14}{*}{$\begin{array}{lr}\text { Sept. } & 25 \\
\text { Oct. } & 3 \\
\text { Oct. } & 8 \\
\text { Oct. } & 9 \\
\text { Oct. } & 11 \\
\text { Oct. } & 14 \\
\text { Oct. } & 16 \\
\text { Oct. } & 25 \\
\text { Nov. } & 13 \\
\text { Nov. } & 19 \\
\text { Nov. } 20 \\
\text { Nov. } 26 \\
\text { Nov. } 27 \\
\text { Dec. } & 3 \\
\text { Dec. } & 11\end{array}$} & $9.5 / 11.8$ & 0 & 0 & - & 18.3 & 0.6 & - & 6.9 & 1.8 & - \\
\hline & - & & - & - & - & 0.4 & - & - & - & - \\
\hline & - & Ope & tion & 一 & 一 & - & 一 & - & - & - \\
\hline & $10.4 / 14.4$ & & - & - & - & 一 & $\overline{\pi \Omega}$ & - & - & - \\
\hline & $8.8 / 12.8$ & 0 & $1+$ & - & 8.4 & - & $75 \%$ & 4.4 & 1.1 & - \\
\hline & $7.7 / 11.0$ & & - & - & - & 37.1 & $75 \%$ & - & - & - \\
\hline & $7.2 / 10.4$ & 0 & $1+$ & 0.5 & - & $\overline{10}$ & - & 4.9 & 1.4 & - \\
\hline & $3.4 / 5.0$ & & - & - & - & 2.2 & - & 6.1 & 1.1 & $21 \%$ \\
\hline & $2 \overline{0 / 2} 5$ & & $\overline{2}$ & $\overline{12}$ & 一 & 3.6 & $\overline{507}$ & $\overline{60}$ & $\overline{12}$ & $\overline{1207}$ \\
\hline & $2.0 / 2.5$ & 1 & $2+$ & 1.3 & 一 & - & $65 \%$ & 6.0 & 1.3 & $12 \%$ \\
\hline & - & & - & - & $\overline{7}$ & $\overline{00}$ & $57 \%$ & - & - & - \\
\hline & $1.4 / 1.5$ & - & - & - & $\begin{array}{l}4.1 \\
-\end{array}$ & 0.9 & - & - & - & - \\
\hline & $1.0 / 1.0$ & & - & 1.3 & - & 0.2 & $45 \%$ & - & - & $6 \%$ \\
\hline & - & $1+$ & $1+$ & - & - & 0.2 & $57 \%$ & 5.0 & 1.1 & - \\
\hline \multirow{5}{*}{\begin{tabular}{lr}
\multicolumn{1}{c}{1952} \\
Mar. & 4 \\
Apr. & 3 \\
May & 13 \\
June & 13
\end{tabular}} & & & & & & & & & & \\
\hline & $0.5 / 0.9$ & & $2+$ & 0.5 & 7.7 & 一 & $60 \%$ & 4.9 & 1.2 & 一 \\
\hline & $1.1 / 1.4$ & & $3+$ & 一 & 7.2 & - & $70 \%$ & 6.9 & 1.4 & 一 \\
\hline & $1.1 / 1.4$ & & $2+$ & - & 5.8 & - & $\overline{-}$ & $\begin{array}{l}5.8 \\
5.9\end{array}$ & $\begin{array}{l}1.2 \\
1.4\end{array}$ & - \\
\hline & $0.7 / 1.1$ & & & & & - & - & 5.2 & 1.4 & \\
\hline
\end{tabular}


TABLE II

The percentage recovery of ammonia nitrogen from standard solutions by the method employed in these investigations, and the range of normal blood determinations measured in healthy human controls

\begin{tabular}{|c|c|c|c|c|c|c|c|}
\hline \multirow[b]{2}{*}{$\begin{array}{c}\text { Determi- } \\
\text { nations }\end{array}$} & \multicolumn{6}{|c|}{$\left(\mathrm{NH}_{4}\right)_{2} \mathrm{SO}_{4}$ solutions containing: } & \multirow[b]{2}{*}{$\begin{array}{l}\text { Normal blood } \\
\text { determinations }\end{array}$} \\
\hline & $\begin{array}{l}0.198 \text { нg. } \\
\text { N/cc. }\end{array}$ & $\begin{array}{l}\text { Per cent } \\
\text { recovery }\end{array}$ & 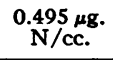 & $\begin{array}{l}\text { Per cent } \\
\text { recovery }\end{array}$ & $\begin{array}{l}1.97 \mu \mathrm{gg} \\
\mathrm{N} / \mathrm{cc} \text {. }\end{array}$ & $\begin{array}{l}\text { Per cent } \\
\text { recovery }\end{array}$ & \\
\hline $\begin{array}{r}1 \\
2 \\
3 \\
4 \\
5 \\
6 \\
7 \\
8 \\
9 \\
10\end{array}$ & $\begin{array}{l}0.193 \\
0.201 \\
0.213 \\
0.189 \\
0.163 \\
0.181 \\
0.201 \\
0.172 \\
0.193 \\
0.218\end{array}$ & $\begin{array}{c}97.5 \\
102 . \\
108 . \\
95.4 \\
82.3 \\
91.4 \\
102 . \\
86.9 \\
97.5 \\
110 .\end{array}$ & $\begin{array}{l}0.500 \\
0.512 \\
0.500 \\
0.462 \\
0.479 \\
0.470 \\
0.513 \\
0.457 \\
0.489 \\
0.489\end{array}$ & $\begin{array}{c}101 . \\
103 . \\
101 . \\
93.3 \\
96.8 \\
95.0 \\
104 . \\
92.3 \\
98.8 \\
98.8\end{array}$ & $\begin{array}{l}1.94 \\
1.97 \\
1.94 \\
1.92 \\
1.97 \\
1.98 \\
1.97 \\
2.01 \\
2.03 \\
2.00\end{array}$ & $\begin{array}{c}99.5 \\
100 . \\
99.5 \\
97.5 \\
100 . \\
101 . \\
100 . \\
102 . \\
103 . \\
102 .\end{array}$ & $\begin{aligned} \text { 1) } & 58.9 \mu \mathrm{g} . ~ \% \\
\text { 2) } & 65.2 \mu \mathrm{g} . \% \\
\text { 3) } & 78.8 \mu \mathrm{g} . \% \\
\text { 4) } & 55.2 \mu \mathrm{g} . \% \\
\text { 5) } & 49.9 \mu \mathrm{g} . \% \\
\text { 6) } & 57.8 \mu \mathrm{g} . \% \\
7) & 57.8 \mu \mathrm{g} . \% \\
\text { 8) } & 62.3 \mu \mathrm{g} . \% \\
\text { 9) } & 71.0 \mu \mathrm{g} . \% \\
\text { 10) } & 50.8 \mu \mathrm{g} . \%\end{aligned}$ \\
\hline $\begin{array}{l}\text { Average } \\
\text { Standard error }\end{array}$ & $\begin{array}{r}0.192 \\
\pm .005\end{array}$ & 96.9 & $\begin{array}{r}0.487 \\
\pm .006\end{array}$ & 98.4 & $\begin{array}{r}1.97 \\
\pm .01\end{array}$ & 100. & $\begin{array}{l}60.8 \mu \mathrm{g} . \% \text { Average } \\
28.9 \mu \mathrm{g} . \% \text { Range }\end{array}$ \\
\hline
\end{tabular}

four; whereas the slightest perceptible alteration of mental function, usually presenting as drowsiness, slowness of response, or incoherence of thought was rated as one. Severe mental confusion with disorientation for time and place, and incontinence of sphincters was recorded as two. In this state the patient talked loudly, wandered about the ward making nonsensical remarks, was often irritable and difficult to manage with a mood that vacillated from gaiety to truculence. Stupor, meaning a significant reduction in spontaneous activity with mental dullness, was graded three. In this latter condition the patient remained in bed or in a chair, was quiet most of the time and was incapable of answering any except the most simple questions regarding his personal identity. It was necessary to depend entirely upon assessment of the state of awareness and responsiveness because the only consistent neurological disorder was in this sphere. When deeply comatose the plantar reflexes were sometimes extensor but more often absent or flexor in type. Tendon reflexes were retained at all times as were pupillary, corneal, and pharyngeal reflexes. Fluctuating rigidity of the limbs, grasp and occasionally sucking reflexes could be evoked during confused and stuporous states. With practice, different observers were able to form similar judgments of the clinical state but it must be admitted that evaluation of the patient was always difficult because of his limited knowledge of English.

The electroencephalographic tracings were graded on a scale of zero, one, two, and three with zero standing for a normal record. The slightest recognizable degree of alteration from normal, rated one on our scale, consisted of some degree of disorganization of the regular wave forms and appearance of random slower waves (four to nine per second frequency) of higher voltage superimposed on a background of alpha waves. An absence of all normal waves and the occurrence of high voltage slow waves (circa two to five per second) were judged to be a three, the greatest degree of abnormality. A rating of two was given to those records which were intermediate, i.e., moderately abnormal with a predominance of four to seven per second wave frequencies. In the more abnormal records there were occasional bursts of bilaterally synchronous, high voltage, slow waves of about two to three per second frequency. More often, however, all semblance of regularity of electrical activity had vanished.

Since elevated levels of blood ammonia had been demonstrated in dogs with Eck fistulas $(6,8)$ and neurological disorders induced in humans with liver disease by the administration of certain nitrogenous substances (13), it was decided to obtain quantitative measurements of blood ammonia levels from day to day during and between these episodes of stupor. A modification of the method devised by Conway (14) was employed. The accuracy and reliability of this modification and the range of values obtained in normal subjects are given in Table II. In brief, the technique was to obtain one milliliter of heparinized venous blood and introduce it immediately into the outer chamber of a diffusion dish containing one milliliter of saturated $\mathrm{K}_{2} \mathrm{CO}_{3}$. Diffusion was allowed to continue for ten minutes at the end of which time a titration of the contents of the inner chamber, which contained one per cent boric acid and an indicator, was carried out with $0.003 \mathrm{~N}$ hydrochloric acid. The amount of ammonia nitrogen in gamma per cent was then determined by calculating from the amount of $.003 \mathrm{~N}$ hydrochloric acid required to titrate the contents of the inner chamber back to its original $\mathrm{pH}$.

The patient remained on a ward in the hospital for a period of approximately six months. During the first part of this period, he was given a standard ward $\operatorname{diet}^{3}$ and a record was kept of his protein intake. Base-line data concerning neurologic status, the electroencephalograms and blood ammonia levels were secured. Whenever there was the slightest derangement of consciousness, these procedures were repeated daily or as often as was deemed necessary to follow his status accurately. Frequent de-

3 Standard ward diet consists of approximately 250 grams of carbohydrates, 80 grams of protein, and 90 grams of fat per day or 2,130 calories. 

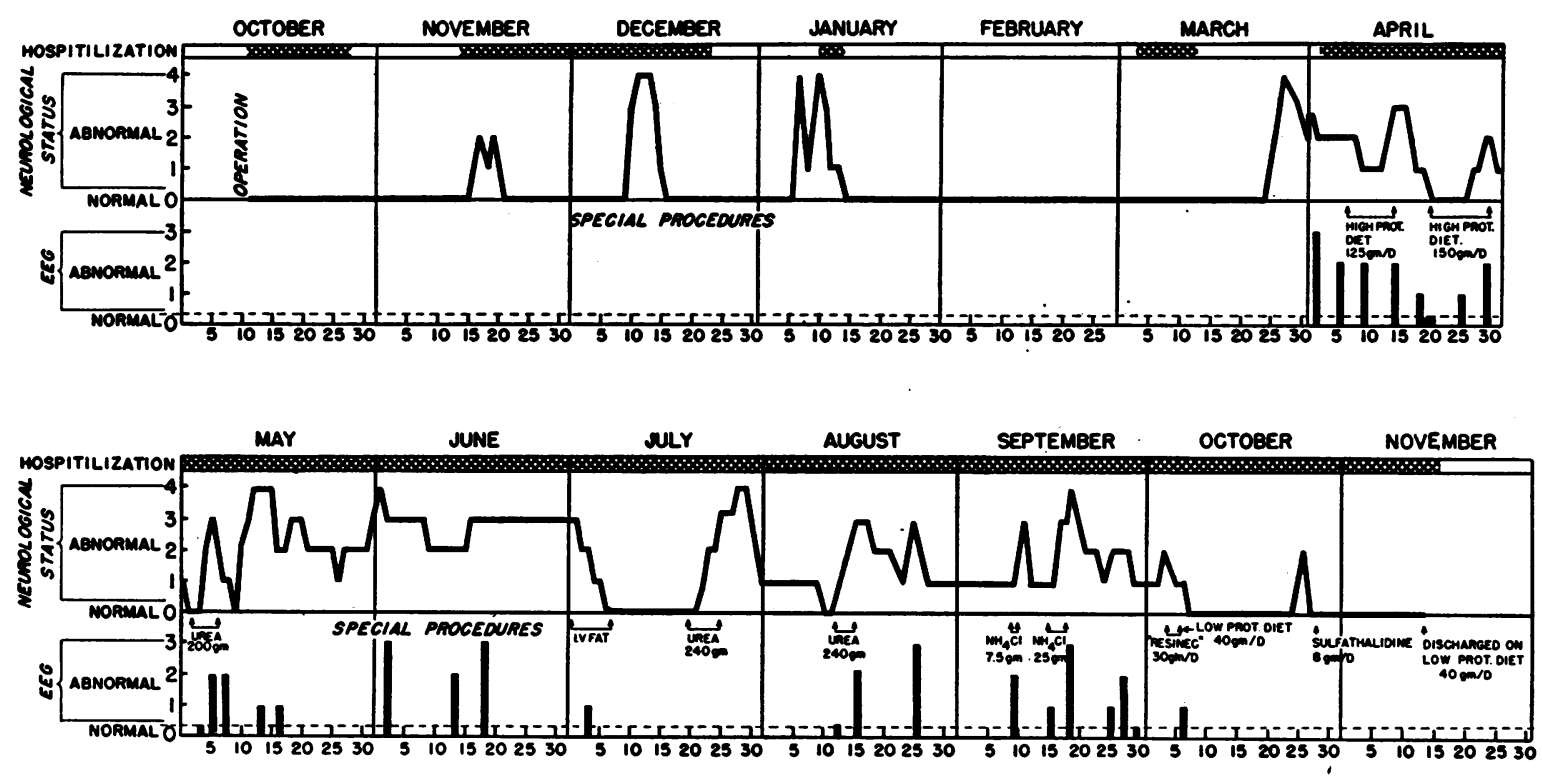

Fig. 1. Diagrammatic Representation of the Patient's Clinical Course, Correlating Neurological Status, Electroencephalographic Tracings and Special Procedures Which Apparently Influenced the Clinical COURSE

terminations of non-protein nitrogen, urea nitrogen, fasting blood sugar, and serum levels of sodium, potassium, and chloride were obtained during the early phases of the study, but as these remained consistently normal, they were later discontinued. The effects of a high protein diet and the oral administration of various nitrogenous substances were investigated.

\section{RESULTS}

In addition to the first four spontaneous episodes of confusion, stupor or coma previously mentioned in the case report, eight other episodes were observed during this long period of hospitalization. These latter were induced deliberately by the administration of excess protein, urea, ammonium chloride or "Resodec" (an ammonium and potassium cation exchange resin) in an attempt to discover the underlying cause of this abnormality. The clinical course of this patient's illness and the pertinent electroencephalographic data are graphically presented in Figure 1. Since the patient's future well-being depended on an understanding of the mechanisms causing this episodic stupor, it was essential to induce them in order to clarify the etiology of this condition and to obtain a basis for rational therapy.

It will be noted from the chart (Figure 1) that the first four episodes of stupor were brief and recovery was rapid (within two to four days) and complete. The only therapy was the parenteral administration of water, glucose, and electrolytes in adequate amounts. Later episodes were prolonged, lasting several days or even weeks at a time, with temporary improvement or worsening, often in relationship to certain specified procedures. The episode of May 10th to May 15th was induced by the oral administration of urea and was undoubtedly the most severe of any witnessed. For nearly a week the patient was in an alarming state of profound coma, manifesting no reaction to any externally applied stimuli. Even in this condition, however, there was no significant alteration of any of the measurable components of the circulating blood except as described below.

The electroencephalogram correlated well with the clinical status of the patient. The slightest mental aberration was always reflected in the electroencephalographic tracing. Moreover the degree of alteration of the electroencephalogram was roughly parallel to the clinical state. When the patient was slightly to moderately confused the electroencephalogram showed random slow waves $(1+)$; when stuporous all normal electrical activity was replaced by 4 to 7 per second slow waves $(2+)$. During deep coma there was a suppression of all normal electrical activity with only random delta waves remaining $(3+)$. With 
the return of normal alertness and responsiveness, the electroencephalogram became normal. Bursts of bilaterally synchronous slow waves of high voltage were observed several times during severe confusion or stupor, when the electroencephalographic records were grossly abnormal.

A finding of special interest was the persistently elevated blood ammonia level even during periods when the patient was mentally clear and the electroencephalographic tracing was normal. In fact when compared with a series of patients on the ward who had neither liver disease nor an Eck fistula our patient's blood levels were always higher by fifty to seventy-five micrograms per cent.

The controlled metabolic study, during which an attempt was made to isolate some of the factors that could possibly be responsible for these episodes of stupor, was begun on April 6th. Since many investigators had reported that animals with Eck fistulae were intolerant of meat, developing "meat intoxication" after being fed liberal quantities of animal protein, it was planned at first to observe the effects of a high protein diet. It was difficult to maintain the proposed intake of one hundred and fifty grams of protein per day because after the first day the patient complained of feeling unwell and refused to eat this amount. An episode of stupor nevertheless occurred after three days on a relatively high protein diet. This experiment was not entirely satisfactory because he had not completely recovered from the episode of coma that brought him to the hospital on March 25th. The high protein diet was reinstituted on April 26th when the patient was mentally clear, and another episode of stupor occurred. Nitrogen balance studies were carried out during this episode but no abnormalities were detected. Dr. R. L. Berg studied the toxic products of proteolysis (8) and kindly analyzed samples of the patient's urine for these toxic substances but found none.

Urea was then given orally in repeated doses of 30 grams for four days. On the fourth day of the first trial of this drug, confusion and stupor developed, a degree of mental disorder that was graded as $3+$. Urea was discontinued and although there seemed to be improvement for one day, this was followed by protracted coma which, as already stated, lasted for a week. During the administration of urea there was a slight rise in blood urea and non-protein nitrogen. No other biochemical abnormality was detected. After the

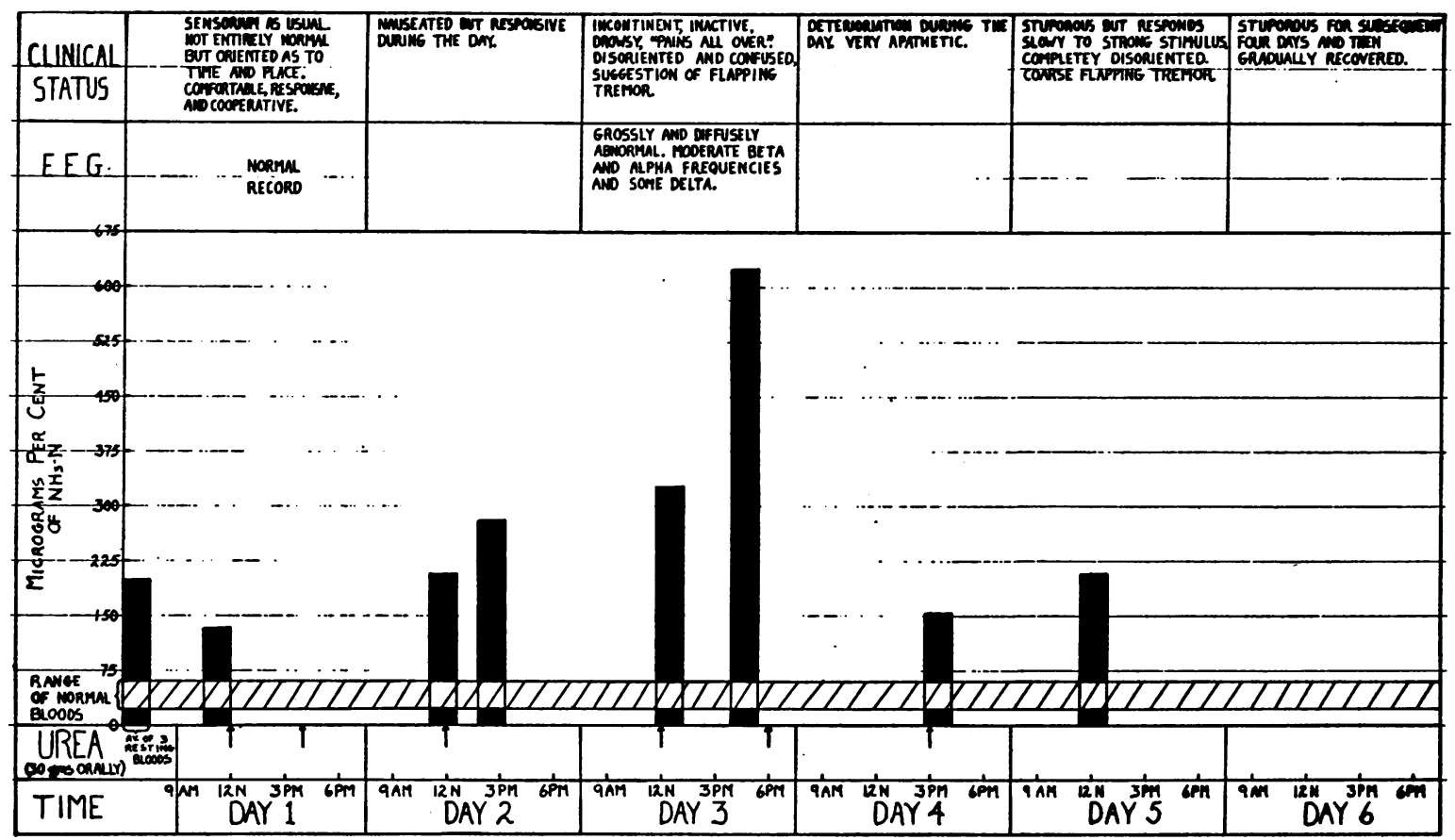

Fig. 2. The Effect of the Oral Administration of Urea on the Clinical Status, the Electroencephalographic Tracings and the Concentration of Ammonia in the Peripheral Blood 


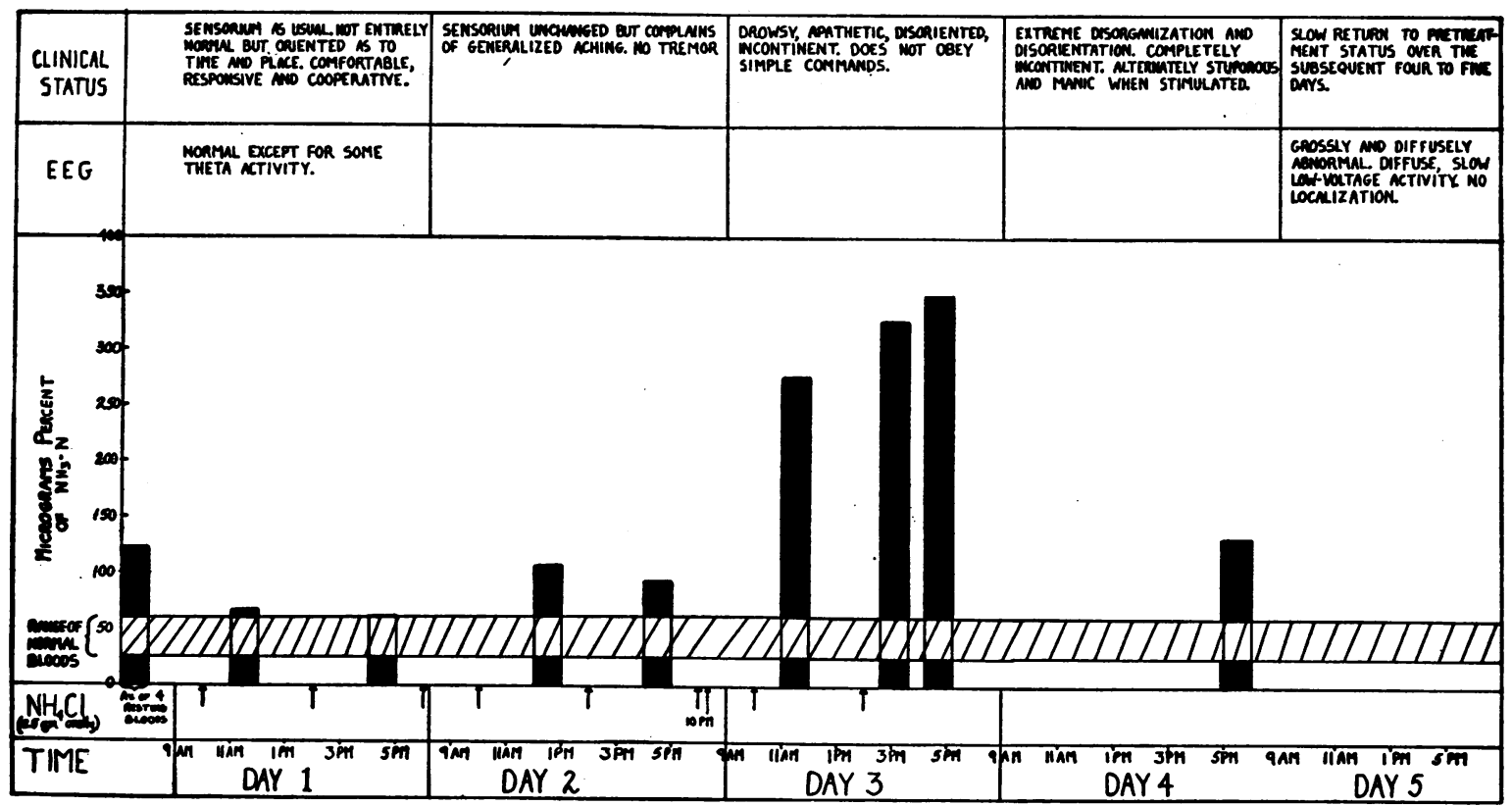

Fig. 3. The Effect of the Oral Administration of Ammonium Chloride on the Clinical Status, the Electroencephalographic Tracings and the Concentration of Ammonia in the Peripheral Blood

technique for analyzing blood ammonia had been perfected, this clinical experiment was cautiously repeated and the results are shown in Figure 2. After approximately 240 grams were given over a period of four days, he became confused and this progressed to stupor and coma despite immediate discontinuance of the drug. Concomitant with the clinical and electroencephalographic changes there was a sharp rise in the levels of ammonia in the blood. Improvement began after one day and recovery was complete within one week. This experiment was then repeated a third time with almost identical results. The repetition of these investigations seemed to be necessary in order to assure ourselves that these episodes of stupor were not coincidental with, rather than dependent on the administration of protein and urea.

It was decided next to study the effect of ammonium containing compounds. Ammonium chloride was administered in two and one-half gram doses to a total dosage of seven and one-half grams. This provoked only a mild and transient disturbance so the dosage was increased to a total of 25 grams in three days. The patient, who was slightly confused at the beginning of this experiment, became more so toward the end of the second day and on the third day was stuporous. The electro- encephalographic abnormality became worse $(3+)$ and the levels of blood ammonia rose concomitantly (Figure 3).

"Resodec," a cation exchange resin, which liberates ammonia in the gastrointestinal tract was then tried. The effect was much the same as that produced by urea and ammonium chloride. After 30 grams were taken orally on two successive days, confusion increased in severity; the electroencephalographic abnormality became more pronounced; and the level of blood ammonia rose. When the resin was withheld, improvement occurred.

We were tempted to repeat many of these experiments and to undertake others which would confirm and elucidate certain obscure points in the pathogenesis of this episodic stupor. However, we had learned something about the mechanism of the clinical syndrome, and further study did not seem to be in the best interest of the patient. A therapeutic program designed to prevent the elevation of blood ammonia was then instituted. On a diet which allowed a maximum protein intake of not more than $\mathbf{4 0}$ grams per day, the patient has remained mentally clear for nearly four months except for two brief episodes of mild confusion lasting one to two days. He has been at 
home and under the supervision of his family. As stated above, the level of blood ammonia during the asymptomatic periods has hovered around 150 micrograms per cent; but when oral sulfathaladine was given with this low protein diet, the ammonia level fell to slightly below 100 micrograms per cent, the upper limit of normal by this particular technique.

\section{DISCUSSION}

It is clear from these clinical data, even though based on but a single case, that a remarkable group of symptoms may be engendered by an Eck fistula in a human. This syndrome, which for convenience has been called episodic stupor, consisted of periods of impaired alertness and a retarded responsiveness which varied in degree from mild confusion to stupor or coma. Focal and lateralizing neurologic signs were absent but many of the accompaniments of confusion, stupor, or coma such as uninhibited and senseless behavior, fluctuating rigidity of the limbs, reflex grasping and sucking, and bilateral extensor plantar reflexes were observed. This episodic disturbance of mental function appeared to occur spontaneously without recognizable antecedent cause. The onset was acute; the course was progressive for one to several days; and recovery was either rapid, i.e., within a day or two, or slower, within one or more weeks. Convulsions were not a part of the syndrome; at least they were never observed in the hospital though once the family reported a twiching of the limbs during stupor. Except for one severe and prolonged episode of coma, following which a slight degree of intellectual impairment persisted for several weeks, recovery was complete and there was no evidence of residual neurologic damage.

It is hardly valid to draw sweeping conclusions from a single case, yet it seems reasonably certain that a highly characteristic neurological syndrome has been induced in a human with an Eck fistula by a high protein intake, by urea, by ammonium chloride, and by an ion-exchange resin which liberates ammonia. The onset of these symptoms has been accompanied by a sharp rise in blood ammonia levels, so it would appear that the ingestion of substances which either contain ammonium ion or which during digestion may form ammonia in the gastrointestinal tract have an adverse effect on the central nervous system.

Although relatively little is known about the metabolism of ammonia in the human, there is a sufficient background of data from animal experiments to postulate a rational explanation for these observations. Ammonia is known to be a very toxic substance. Baldwin (15) has summarized the mechanisms by which several species eliminate ammonia, and concluded that "conversion of ammonia to other products is an indispensable adaptation to limitation of the availability of water." In the human, this adaptation takes the form of synthesis of urea in the liver, probably through the mechanism of the ornithine cycle as postulated by Krebs (16). Regardless of the details of this mechanism, it is well-established that an adequately functioning liver is essential in mammals for the elimination of ammonia (17). The kidneys are believed to have no part in the removal and, in fact, actually contribute to the total ammonia formed in the organism (18). All the sources of ammonia formation are not known but in addition to the processes of deamination within the body, ammonia is formed within the gastrointestinal tract by the action of urea-splitting micro-organisms and presumably is absorbed in relatively high concentrations into the portal system (19).

If the data from the investigation of mammals are applicable to the human, it is reasonable to suppose that, with an Eck fistula in which the blood in the portal system by-passes the liver, the organism is unable to detoxify the relatively large amounts of ammonia entering the portal system from the gastrointestinal tract with sufficient rapidity to prevent an elevation of ammonia concentration in the systemic circulation. This elevated level of ammonia may well interfere, directly or indirectly, with the metabolism of the central nervous system. The relationship between the neurological symptoms and ammonia levels in the blood is not an exact and reciprocal one, however. The onset of the syndrome of episodic stupor has been consistently correlated with a high blood ammonia level, but the blood level falls rapidly when the ingestion of ammonia containing compounds is discontinued whereas the central nervous system symptoms continue for some hours or days. It may be that the elevation in blood ammonia which was consistently 
observed at the onset of symptoms, was only a reflection of an unknown disturbance in the complex mechanisms by which ammonia is metabolized in the body.

The neurologic syndrome in our case resembled "hepatic coma" in many respects. The rapid impairment of consciousness with attendant electroencephalographic abnormalities is common to both conditions. Inability to sustain the contraction of groups of muscles causing a flapping movement of the outstretched hands which has been found in a majority of cases of hepatic coma, was seen but infrequently. It may be recalled that Phillips, Schwartz, Gabuzda, and Davidson (13) were able to induce in patients with cirrhosis of the liver, a syndrome resembling "hepatic coma" by the oral administration of urea, ammonium chloride, diammonium citrate and "Resodec." If central nervous system symptoms can be precipitated by absorbed ammonia from the gastrointestinal tract by-passing the liver via an Eck fistula, it is reasonable to suppose that hepatocellular damage might interfere with the normal synthesis of ammonia to urea and have the same effect. In either instance there would be an impairment of certain of the metabolic activities of other organs, particularly the brain. It is also possible that shunting of blood directly from the portal to the caval system occurs in many cases of chronic liver disease, and that the factors operating in our case of human Eck fistula also play a role in the genesis of hepatic coma. This whole problem requires further study.

From the available evidence the conclusion that there was no serious degree of liver disease in our case is probably justified. Although the patient was jaundiced for several weeks before operation, direct inspection of the liver disclosed only bile stasis without atrophy or biliary cirrhosis. Also, repeated tests of hepatic function failed to demonstrate any consistent abnormalities. Considering, however, the acknowledged inadequacy of current tests of liver function and the changes which are known to occur in the liver of the dog after the construction of an Eck fistula, one must admit of the possibility that some degree of hepatic derangement did exist.

The relationship between this syndrome of episodic stupor in the human and "meat intoxication" in the dog also needs further clarification.
Finally attention should be called to the fact that the chemical disturbance attending an Eck fistula in humans deserves to be ranked with hypoglycemia, acidosis, uremia, hypokalemia, hyponatremia, and porphyria as a cause of episodic stupor or coma.

\section{CONCLUSIONS}

1. In a human with a surgical Eck fistula a characteristic syndrome of episodic stupor has been induced by the oral administration of substances which contain or liberate ammonia.

2. The onset of symptoms has been correlated with a sharp rise in the levels of ammonia in the peripheral blood and with reversible electroencephalographic changes similar in many respects to those observed in "hepatic coma."

3. The possible implications of these observations in providing an explanation of the "meat intoxication" syndrome in dogs with Eck fistula and of "hepatic coma" in man have been discussed.

Addendum: The patient died on July 30,1953, after this article was submitted for publication. Death did not appear to be related to hepatic insufficiency or ammonia intoxication but rather to age, arteriosclerotic heart disease and possibly nutritional deficiency. At autopsy the liver showed diffuse fatty infiltration but no cirrhosis. There was degeneration of the cerebral cortex in places and throughout the gray matter a diffuse hyperplasia of the protoplasmic astrocytes. No evidence of carcinoma of the pancreas was found.

\section{REFERENCES}

1. Eck, N. V., K. voprosu o perevyazkie vorotnois veni. Predvaritelnoye soobshtshjenye. (Ligature of portal vein). Voen. Med. J., 1877, 130; Translation by Child, C. G., Surg., Gynec. \& Obst., 1953, 96, 375.

2. Crandall, L. A., Jr., and Anderson, M. X., Estimation of the state of hydration of the body by the amount of water available for the solution of sodium thiocyanate. Am. J. Digest. Dis. \& Nutrition, 1934, 1, 126.

3. Whipple, G. H., Robscheit-Robbins, F. S., and Hawkins, W. B., Eck fistula liver subnormal in producing hemoglobin and plasma proteins on diets rich in liver and iron. J. Exper. Med., 1945, 81, 171.

4. Winter, I. C., Van Dolah, J. E., and Crandall, L. A., Jr., Lowered serum lipid levels in the Eck fistula dog. Am. J. Physiol., 1941, 133, 566.

5. Smith, H. P., and Whipple, G. H., Bile salt metabolism. IX. Eck fistula modifies bile salt output. J. Biol. Chem., 1930, 89, 739. 
6. Hahn, M., Massen, O., Nencki, M., and Pawlow, J., Die Eck'sche fistel zwischen der unteren hohlvene und der pfortader und ihre folgen für den organismus. Arch. F. exper. Path. u. Pharmakol., 1893, 32, 161.

7. Baló, J., and Korpássy, B., The encephalitis of dogs with Eck fistula fed on meat. Arch. Path., 1932, 13, 80 .

8. Monguio, J., and Krause, F., Utber die Bedeutung des $\mathrm{NH}_{3}$-Gehaltes des Blutes für die Beurteilung der Leberfunktion. Studien am normalen, lebergesch ä digten und Eckschen Fistelhund. Klin. Wchnschr., 1934, 13, 1142.

9. Freeman, S., Effect of Eck fistula formation, simple portal obstruction and 'meat intoxication' on serum phosphatase and dye clearance of adult dogs. Am. J. Physiol., 1949, 159, 351.

10. Matthews, S. A., Ammonia, a causative factor in meat poisoning in Eck fistula dogs. Am. J. Physiol., 1922, 59, 459.

11. Edwards, E. A., Functional anatomy of the portasystemic communications. Arch. Int. Med., 1951, 88, 137.

12. McDermott, W. V., Jr., A one-stage pancreatoduodenectomy with resection of the portal vein for carcinoma of the pancreas. Ann. Surg., 1952, 136, No. 6, 1012.

13. Phillips, G. B., Schwartz, R., Gabuzda, G. J., Jr., and Davidson, C. S., The syndrome of impending he- patic coma in patients with cirrhosis of the liver given certain nitrogenous substances. New England J. Med., 1952, 247, 239.

14. Conway, E. J., Apparatus for the micro-determination of certain volatile substances. IV. The blood ammonia, with observations on normal human blood. Biochem. J., 1935, 29, 2755.

15. Baldwin, E., Dynamic Aspects of Biochemistry. Chapter $\mathrm{X}-$ Excretory metabolism of proteins and amino acids. University Press, Cambridge, England, 1947.

16. Krebs, H. A., Chapter 67-Urea Synthesis in The Enzymes, New York, Academic Press Inc., 1952, vol. 2, part 2.

17. Bollman, J. L., and Mann, F. C., Studies on the physiology of the liver. XVIII. The effect of removal of the liver on the formation of ammonia. Am. J. Physiol., 1930, 92, 92.

18. Nash, T. P., Jr., and Benedict, S. R., The ammonia content of the blood, and its bearing on the mechanism of acid neutralization in the animal organism. J. Biol. Chem., 1921, 48, 463.

19. Folin, O., and Denis, W., Protein metabolism from the standpoint of blood and tissue analysis. Second paper-The origin and significance of the ammonia in the portal blood. J. Biol. Chem., 1912, 11, 161.

\section{SPECIAL NOTICE TO SUBSCRIBERS}

Post Offices will no longer forward the Journal when you move.

Please notify The Journal of Clinical Investigation, Business Office, 622 West 168th Street, New York 32, N. Y. at once when you have a change of address, and do not omit the zone number if there is one. 